\title{
Transmission, Characterization, and Serology of a Luteovirus Associated with Yellow Leaf Syndrome of Sugarcane
}

\author{
Sandra Mansur Scagliusi and B. E. L. Lockhart
}

Department of Plant Pathology, University of Minnesota, St. Paul 55108.

Accepted for publication 13 October 1999.

\begin{abstract}
Scagliusi, S. M., and Lockhart, B. E. L. 2000. Transmission, characterization, and serology of a luteovirus associated with yellow leaf syndrome of sugarcane. Phytopathology 90:120-124.

A previously uncharacterized luteovirus was associated with one form of yellow leaf syndrome (YLS), a widespread disease of sugarcane (Saccharum sp.). The virus was named Sugarcane yellow leaf luteovirus (ScYLV), and was identified in major sugarcane-producing areas of the world. Typical disease symptoms were reproduced when ScYLV was transmitted by Melanaphis sacchari or Rhopalosiphum maidis from infected to healthy sugarcane, suggesting that this virus may be the causal agent of one form

spp. Virions of ScYLV were 24 to $29 \mathrm{~nm}$ in diameter in sodium phosphotungstate at $\mathrm{pH} 5.0$, had a buoyant density of $1.30 \mathrm{~g} / \mathrm{cm}^{3}$ in $\mathrm{Cs}_{2} \mathrm{SO}_{4}$, and contained a $5.8-\mathrm{kb}$ genomic ssRNA. The capsid protein had an estimated relative molecular mass of $27 \mathrm{kDa}$ and was not glycosylated. A polyclonal rabbit antiserum raised against ScYLV did not detect any of eight other luteoviruses by enzyme-linked immunosorbent assay or immunosorbent electron microscopy, but in immunoblot assays, antibodies to ScYLV detected the RPV serotype of Barley yellow dwarf luteovirus. It is concluded that ScYLV is a previously undescribed luteovirus that is biologically and serologically distinct from other members of the group and may be the causal agent of one form of YLS of sugarcane.
\end{abstract} of YLS. The only known hosts of ScYLV are Saccharum and Erianthus
A disorder of sugarcane (Saccharum sp.) characterized by pronounced yellowing of the midrib (Fig. 1A), and accompanied in some cases by yellowing of the lamina and dwarfing of terminal internodes, was first reported from East Africa during the 1960s (16). The disorder was referred to as yellow wilt (16) and later as yellow leaf syndrome (YLS), and was reported to occur in a number of sugarcane-producing areas $(2,14,16,18,20,22)$. In some instances, YLS was associated with significant yield losses or a decline in productivity of some important sugarcane cultivars $(9,14,20,23)$.

The etiology of YLS has been in doubt for some time. Abiotic factors, including soil compaction, nutrient imbalances, waterlogging, and aberrant climatic patterns were suggested as possible causes (14). However, patterns of symptom distribution in the field suggested a biotic rather than an abiotic cause (14), and this view was supported by reports of the association of luteovirus-like particles with YLS $(14,22,23)$. Previous reports, which were based on doublestranded RNA analysis, suggested that a clostero-like virus might be associated with YLS $(5,18)$, but these findings have not been substantiated. This report describes the transmission, characterization, and serology of a virus to be named Sugarcane yellow leaf luteovirus (ScYLV), and presents evidence that suggests ScYLV is a previously undescribed luteovirus that may be the causal agent of one form of YLS of sugarcane.

\section{MATERIALS AND METHODS}

Virus source. Five naturally infected sugarcane cultivars that consistently developed YLS and gave the highest yields of ScYLV virions were used as sources of virus for this study. These cultivars and their sources were CP 65-357 (Florida), H 73-6110 (Hawaii), SP 71-6163 (Brazil), SP 71-1406 (Brazil), and RB 72-454 (Brazil). The virus was purified from source plants grown in the greenhouse,

Corresponding author: B. E. L. Lockhart; E-mail address: plpa@puccini.crl.umn.edu

Publication no. P-1999-1115-01R

(C) 2000 The American Phytopathological Society because field-collected leaf tissue was contaminated with bacteriophages associated with phylloplane bacteria, and it was not possible to eliminate these contaminants from purified preparations of ScYLV.

Transmission tests. Transmission tests were done by mechanical inoculation and with aphids. Mechanical inoculation was performed using partially purified extracts prepared as described (1) from symptomatic leaf tissue of the sugarcane cv. CP 65-357. The partially purified extracts were examined by electron microscopy (EM) to verify that they contained isometric virus-like particles, and were used to rub-inoculate Carborundum-dusted leaves of five healthy test plants each of sugarcane cvs. CP 65-357 and H 65-7052, sweet corn (Zea mays L. 'Early Sunglow'), sorghum (Sorghum bicolor L.), and johnsongrass (Sorghum halepense L.). Inoculated sugarcane test plants were observed for 12 months postinoculation for symptom development, and were indexed at 6 and 12 months postinoculation by EM and immunosorbent electron microscopy (ISEM) with partially purified extracts and by double-antibody sandwich enzyme-linked immunosorbent assay (DAS-ELISA) with sap extracts. Mechanically inoculated test plants of sweet corn, sorghum, and johnsongrass were kept for 3 months postinoculation, and were observed for symptom development. At the end of this observation period, the plants were indexed by EM, ISEM, and DAS-ELISA as described above.

Initial aphid transmission tests were performed with Melanaphis sacchari (Zehntner), Rhopalosiphum maidis (Fitch), and Sipha flava (Forbes), three aphid species which colonize sugarcane (4). The objective of these initial tests was to determine whether YLS and the associated isometric virus-like particles could be transmitted by these aphid species from symptomatic to healthy sugarcane. The three aphid species were raised on plants of sugarcane cv. CP 65-357 that showed symptoms typical of YLS and were shown to contain isometric virus-like particles by EM examination of partially purified extracts. Portions of leaf tissue bearing 20 to 30 aphids were placed in the whorl of the emerging leaf of each of five healthy cv. CP 65-357 test plants. After 48 to $72 \mathrm{~h}$, when the aphids had moved onto the test plants and had been allowed an inocu- 
lation access period of at least $12 \mathrm{~h}$, they were killed with insecticide. Controls consisted of healthy test plants infested with aphids raised on YLS-free sugarcane. Test plants were kept for 12 months postinoculation, and were observed for symptom development and indexed by EM, ISEM, and DAS-ELISA for presence of ScYLV. These aphid transmission tests were repeated once. A second series of aphid transmission tests were performed with $R$. maidis alone. The objective of these tests, which were done once, was to determine whether $R$. maidis could transmit YLS and the associated ScYLV from sugarcane to sweet corn, sorghum, and johnsongrass. Transmission tests with $R$. maidis were performed as described above. Sweet corn, sorghum, and johnsongrass plants were kept for 2 to 3 months postinoculation, observed for symptom development, and indexed for presence of ScYLV by EM, ISEM, and DAS-ELISA as described above.

Virus purification. Greenhouse-grown leaf tissue of YLS-infected sugarcane cvs. CP 65-357, H 73-6110, SP 71-6163, SP 711406 , and RB $72-454$ was chopped and frozen at $-90^{\circ} \mathrm{C}$. Frozen tissue was powdered in an electric coffee grinder with dry ice and mixed with 3 volumes (wt/vol) of $250 \mathrm{mM}$ sodium-potassium phosphate buffer, $\mathrm{pH} 6.0$, containing $0.2 \%$ (vol/vol) 2-mercaptoethanol and $2 \%$ (vol/vol) Celluclast $1.5 \mathrm{~L}$ (Novo Nordisk Biochem North America Inc., Franklinton, NC) (26). The mixture was stirred for $4 \mathrm{~h}$ at room temperature, blended for 1 to $2 \mathrm{~min}$, and filtered through cheesecloth. The fiber was reextracted with 1 volume of extraction buffer minus Celluclast $1.5 \mathrm{~L}$, and the filtrates were pooled. Triton X-100 was added to a final concentration of $0.8 \%(\mathrm{vol} / \mathrm{vol})$, and the mixture was stirred overnight at $4{ }^{\circ} \mathrm{C}$. The extract was clarified by extraction with an equal volume of chloroform $/ n$-butanol $(1: 1, \mathrm{vol} / \mathrm{vol})$ followed by centrifugation at $12,000 \times g$ (maximum) for $15 \mathrm{~min}$. The aqueous phase was recovered and the virus concentrated by addition of $10 \%$ (wt/vol) polyethylene glycol (average molecular weight $=10,000)$ and $2 \%(w t / v o l) ~ N a C l$. The precipitate was recovered by centrifugation at $12,000 \times g$ (maximum) for $20 \mathrm{~min}$, and the pellets were resuspended in $100 \mathrm{mM}$ sodium-

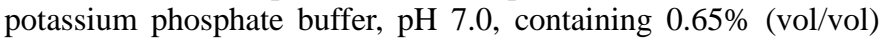
Triton X-100. The partially purified extract was clarified by centrifugation at $20,000 \times g$ (maximum) for $15 \mathrm{~min}$, and the virus was concentrated further by centrifugation at $148,000 \times g$ (maximum) for 90 min through a $5-\mathrm{ml}$ cushion of $30 \%$ sucrose in $100 \mathrm{mM}$ sodium-potassium phosphate buffer, $\mathrm{pH}$ 7.0. The resulting pellets were resuspended in $100 \mathrm{mM}$ sodium-potassium phosphate buffer, $\mathrm{pH} 7.0$, and purified further by rate-zonal centrifugation in 10 to
$40 \%$ sucrose density gradients in the same buffer at $130,000 \times g$ (maximum) for $3 \mathrm{~h}$ at $6^{\circ} \mathrm{C}$. The gradients were fractionated into $1-\mathrm{ml}$ aliquots from the bottom, using a density gradient fractionator (ISCO, Inc., Lincoln, NE) and Fluorinert FC-40 (Sigma-Aldrich Chemical Co., St. Louis) as chase liquid. Virus-containing fractions were identified by EM. Virus-containing fractions free of host plant debris were pooled, and the virus was separated from residual cellular debris by isopycnic banding in $31 \%$ (wt/vol) $\mathrm{Cs}_{2} \mathrm{SO}_{4}$ in $100 \mathrm{mM}$ sodium-phosphate buffer, $\mathrm{pH}$ 7.0, at 223,000 $\times \mathrm{g}$ (maximum) for $24 \mathrm{~h}$ at $20^{\circ} \mathrm{C}$. The virion band was identified by light scattering, collected by syringe, examined by EM to verify purity, and dialyzed for $24 \mathrm{~h}$ against three changes of $100 \mathrm{mM}$ sodiumpotassium phosphate buffer, $\mathrm{pH} 7.0$, to eliminate $\mathrm{Cs}_{2} \mathrm{SO}_{4}$. Virus concentration in purified preparations was estimated using an assumed extinction coefficient of 8.6 (21).

Electron microscopy. Purified and partially purified preparations of ScYLV were mounted on carbon-coated Formvar grids and stained with $2 \%$ sodium phosphotungstate, $\mathrm{pH}$ 5.0, (PTA) containing bacitracin at $100 \mu \mathrm{g} / \mathrm{ml}$. ISEM was done as described (13). Microscope magnification was calibrated using the crystal lattice spacing of stained catalase crystals (28).

Antiserum production and serological tests. Polyclonal antisera were prepared by immunizing New Zealand White rabbits with a primary subcutaneous injection of $50 \mu \mathrm{g}$ of virus emulsified in Hunter's TiterMax adjuvant (Sigma-Aldrich). Three subcutaneous injections of $20 \mu \mathrm{g}$ of virus emulsified in Freund's incomplete adjuvant were administered subsequently at intervals of 2 weeks. Blood samples were collected at weekly intervals beginning 2 weeks after the last injection.

DAS-ELISA was performed as described (7), with some modifications. Antigen samples were prepared by grinding leaf tissue 1:5 (wt/vol) in $100 \mathrm{mM}$ sodium-potassium phosphate buffer, $\mathrm{pH} 6.0$, $0.5 \%$ (vol/vol) 2-mercaptoethanol, and $0.05 \%$ (vol/vol) Tween 20. Immunoglobulin-alkaline phosphatase conjugate was diluted in $20 \mathrm{mM}$ Tris- $\mathrm{HCl}, 150 \mathrm{mM} \mathrm{NaCl}, 0.05 \%$ (vol/vol) Tween 20, pH 7.4 (TTBS), containing $0.2 \%$ (wt/vol) bovine serum albumin and $2 \%$ blotting grade nonfat dry milk (Bio-Rad, Hercules, CA). Prior to addition of substrate, microtiter plates were rinsed with TTBS instead of phosphate-buffered saline containing $0.05 \%$ Tween 20 (PBST) (7). Samples of antisera against Barley yellow dwarf luteovirus (BYD), BYDV-PAV, BYDV-MAV, BYDV-RMV, and BYDV-SGV, were obtained from Agdia (Elkhart, IN). Antiserum against BYDVRPV was produced previously in our laboratory. Potato leafroll
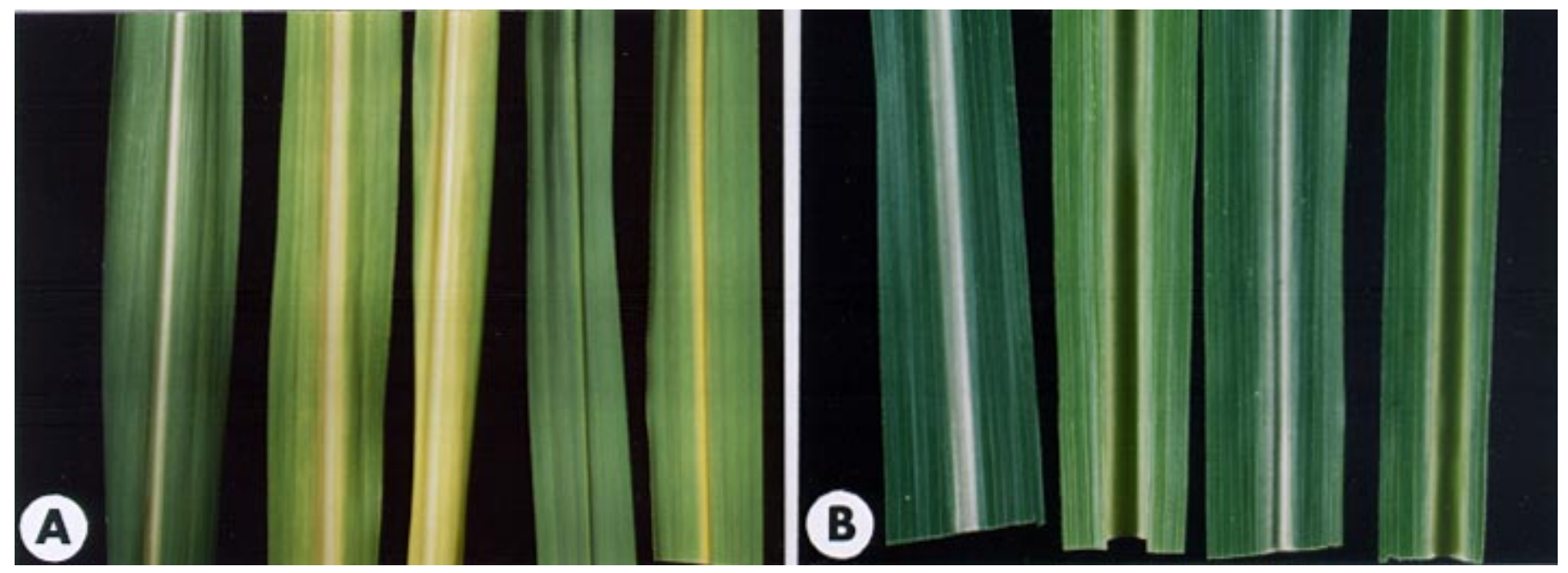

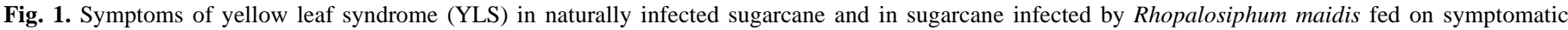

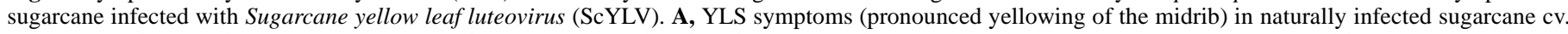

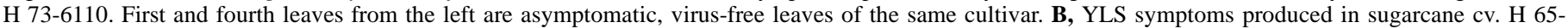

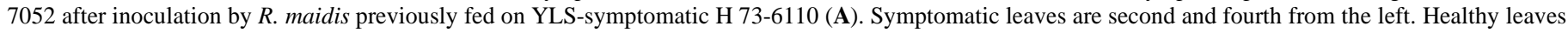

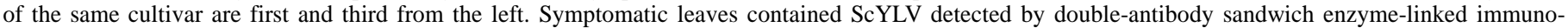
sorbent assay and immunosorbent electron microscopy. No virus was detected in healthy controls 
virus (PLRV) and Beet western yellows virus (BWYV) antisera were obtained from the American Type Culture Collection (Manassas, VA). Monoclonal antibodies against Bean leafroll virus (BLRV) were obtained from P. Jones (Rothamsted Experiment Station, Hertfordshire, England). Samples of BYDV-PAV, BYDV-MAV, BYDV-RPV, BYDV-RMV, and BYDV-SGV antigen in oat leaf tissue were supplied by F. Gildow (The Pennsylvania State University, University Park).

Electrophoretic analysis of ScYLV proteins. Virions of ScYLV purified by isopycnic banding in $\mathrm{Cs}_{2} \mathrm{SO}_{4}$ were subjected to sodium dodecyl sulfate-polyacrylamide gel electrophoresis (SDS-PAGE) in a discontinuous system (10) consisting of a 5\% stacking gel and a $12 \%$ resolving gel. Electrophoresis was performed at $110 \mathrm{~V}$ for $105 \mathrm{~min}$ in a Mini-Protean vertical slab gel electrophoresis unit (Bio-Rad). Polypeptide bands were visualized by staining with Coomassie brilliant blue R-250 (Sigma-Aldrich) and relative molecular masses $\left(M_{\mathrm{r}}\right)$ of polypeptides were estimated by exponential regression analysis with a 10-kDa protein ladder (GIBCO Bethesda Research Laboratories, Gaithesburg, MO) as markers.

Immunoblotting (western blotting) was done after electrophoretic transfer of polypeptides to nitrocellulose membranes after SDS-PAGE. Membranes were blocked for $2 \mathrm{~min}$ in 2\% (vol/vol) Tween 20 and incubated overnight at $4{ }^{\circ} \mathrm{C}$ with primary antibody (whole serum) diluted 1:5,000 in TTBS containing 1\% gelatin. Detecting goat antirabbit immunoglobulin $\mathrm{G}$ ( $\mathrm{IgG}$ )-alkaline phosphatase conjugate (Sigma-Aldrich) was used at a 1:30,000 dilution in TTBS containing 1\% gelatin. Biotinylated protein molecular weight markers (Bio-Rad) were detected with Extravidin-alkaline phosphatase conjugate (Sigma-Aldrich). Protein bands were visualized with 5-bromo-4-chloro-3-indolyl phosphate and nitroblue tetrazolium (BCIP/NBT). Glycoprotein assays were performed on nitrocellulose membranes to which polypeptides had been transferred electrophoretically after SDS-PAGE. Glycoprotein moieties were detected using a Bio-Rad glycoprotein immunoblot kit according to the manufacturer's instructions.

Nucleic acid extraction and electrophoretic analysis. Purified virus was resuspended in $200 \mu \mathrm{l}$ of $10 \mathrm{mM}$ Tris- $\mathrm{HCl}, 6 \mathrm{mM} \mathrm{MgCl}_{2}$,

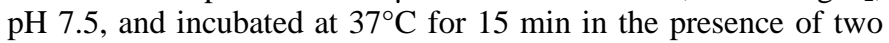
units of ribonuclease-free deoxyribonuclease (RQ1 DNase, Promega Corp, Madison, WI) to digest residual plant DNA. Proteinase $\mathrm{K}$ and SDS were then added to final concentrations of $1 \mu \mathrm{g} / \mu \mathrm{l}$ and $0.5 \%$

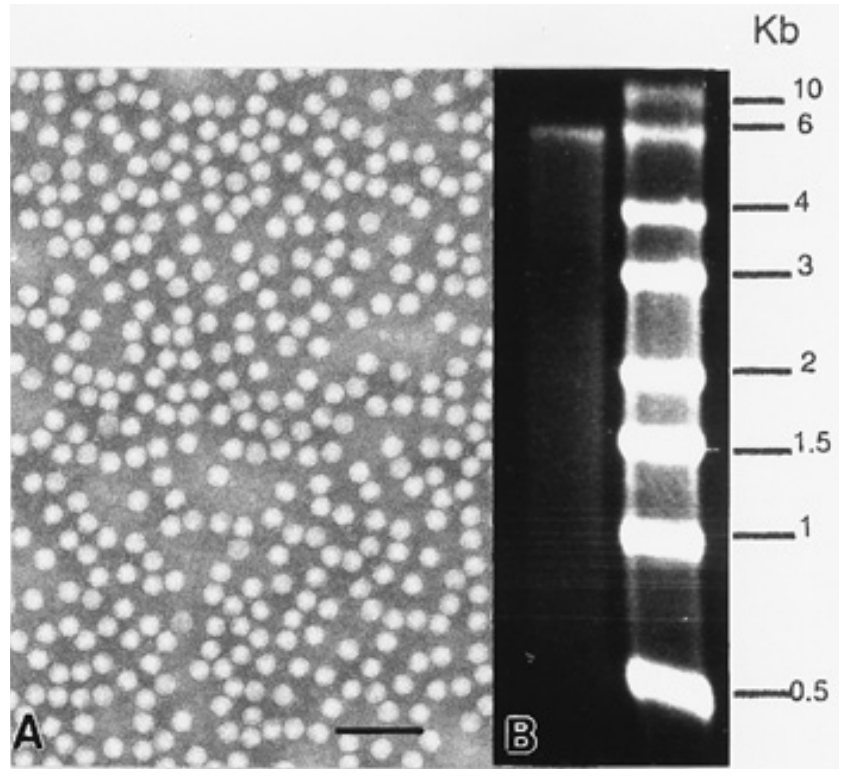

Fig. 2. Virions of Sugarcane yellow leaf luteovirus (ScYLV) and extracted genomic RNA. A, Purified preparation of ScYLV negatively stained with $2 \%$ sodium phosphotungstate, $\mathrm{pH} 5.0$. Scale bar $=100 \mathrm{~nm}$. B, ScYLV genomic RNA visualized by ethidium bromide staining after agarose gel electrophoresis under denaturing conditions (left lane). Right lane contains ssRNA molecular weight markers; sizes are indicated to the right. (wt/vol), respectively, and the mixture was incubated at $37^{\circ} \mathrm{C}$ for $30 \mathrm{~min}$. The solution was extracted twice with an equal volume of phenol/chloroform/isoamyl alcohol (25:24:1), and twice with chloroform/isoamyl alcohol (24:1), and the nucleic acid was precipitated by addition of 0.1 volume of $3 \mathrm{M}$ sodium acetate, $\mathrm{pH} 5.5$, and 1 volume of isopropanol. The precipitate was collected by centrifugation at $20,800 \times g$ (maximum) for $30 \mathrm{~min}$, rinsed with $70 \%$ ethanol, vacuum-dried, and resuspended in $10 \mathrm{mM}$ Tris-HCl, $1 \mathrm{mM}$ EDTA, pH 7.5 (TE buffer). Type and strandedness of the nucleic acid were determined by digestion with DNase, RNase, and S-1 nuclease as described (12). Nucleic acid size was estimated by electrophoresis of glyoxalated samples in $1 \%$ denaturing agarose gels in $50 \mathrm{mM} \mathrm{3-}$ $\mathrm{N}$-morpholinopropanesulfonic acid (MOPS), $40 \mathrm{mM}$ sodium acetate, and 5 mM EDTA, pH 7.0 (19). Single-stranded RNA molecular size markers $(0.2$ to $10 \mathrm{~kb})$ were obtained from Sigma-Aldrich.

\section{RESULTS}

Disease and virus transmission. No symptoms were observed in any of five plants each of sugarcane cv. CP 65-357, sweet corn, sorghum, and johnsongrass that were inoculated mechanically with partially purified extracts from YLS-infected sugarcane. No virions or antigen of ScYLV were detected by EM, ISEM, or DAS-ELISA in these test plants.

Midrib yellowing, characteristic of YLS, was observed in 10 of 10 sugarcane test plants to which either M. sacchari or $R$. padi had been transferred from YLS source plants. However, symptoms did not appear uniformly. Midrib yellowing was observed in one plant at 6 weeks after aphid inoculation, in a second plant at 8 weeks postinoculation, and sporadically in the remaining plants over a period of 10 months. The presence of ScYLV in all symptomatic test plants was demonstrated by ISEM and DAS-ELISA. Plants to which $S$. flava had been transferred from YLS source plants did not develop symptoms of midrib yellowing and did not contain detectable ScYLV virions or antigen. No symptoms were observed on plants of sweet corn, sorghum, and johnsongrass to which $R$. padi had been transferred from YLS source plants, and no ScYLV virions or antigen were detected by ISEM or DAS-ELISA in these plants.

Geographic distribution of ScYLV. Virions and antigen of ScYLV were detected by EM, ISEM, and DAS-ELISA in samples of YLSinfected sugarcane leaf tissue from Australia, Brazil, Colombia, Florida, Guadeloupe, Hawaii, Louisiana, Malawi, Mauritius, Reunion Island, Texas, and South Africa. Several samples of sugarcane showing YLS-like symptoms in Costa Rica and Colombia did not contain detectable ScYLV virions or antigen.

TABLE 1. Reaction of polyclonal antibodies to Sugarcane yellow leaf luteovirus (ScYLV) with ScYLV, Barley yellow dwarf (BYDV), and Potato leafroll (PLRV) luteovirus antigens in double-antibody sandwich enzyme linked immunosorbent assay

\begin{tabular}{ll}
\hline Antigen source & $A_{405}{ }^{\mathrm{a}}$ \\
\hline Healthy sugarcane & 0.084 \\
Yellow leaf syndrome-infected sugarcane & \\
$\quad$ cv. CP 65-357 (Florida) & 0.880 \\
cv. H 73-6110 (Hawaii) & 0.775 \\
cv. SP 79-1011 (Brazil) & 0.765 \\
cv. RB 83-5486 (Brazil) & 0.814 \\
Healthy potato & 0.055 \\
PLRV-infected potato & 0.055 \\
Healthy oat & 0.035 \\
Infected oat & \\
BYDV-PAV & 0.046 \\
BYDV-MAV & 0.040 \\
BYDV-RPV & 0.045 \\
BYDV-RMV & 0.050 \\
BYDV-SGV & 0.050 \\
\hline
\end{tabular}

Absorbance values at $405 \mathrm{~nm}$ represent mean values of four replicate wells per treatment measured $2 \mathrm{~h}$ after addition of substrate. 
Virus purification and particle properties. The purification procedure described above yielded preparations that were free of host plant contaminants (Fig. 2A). Yields of purified virus were $\approx 200 \mu \mathrm{g} / \mathrm{kg}$ of leaf tissue. Substantially less virus was obtained when Celluclast 1.5 L was omitted from the extraction buffer. Virions of ScYLV measured 24 to $29 \mathrm{~nm}$ in diameter when stained with PTA at pH 5.0. In PTA at pH 6.0 or 7.0, they became swollen and variable in size. Purified virus suspensions had an $A_{260} / A_{280}$ ratio of 1.7 to 1.9 , and the virions a buoyant density of $1.30 \mathrm{~g} / \mathrm{cm}^{3}$ in $\mathrm{Cs}_{2} \mathrm{SO}_{4}$. Virions were stable in $\mathrm{Cs}_{2} \mathrm{SO}_{4}$ at $\mathrm{pH} 7.0$, but were less stable at pH 6.0 or 8.0.

Serology. A polyclonal rabbit antiserum raised against a mixture of ScYLV isolates from Brazil, Florida, and Hawaii detected the homologous antigens and ScYLV isolates (Table 1) from Australia, Guadeloupe, Louisiana, Mauritius, South Africa, and Texas (data not shown) by DAS-ELISA. In these tests, the five BYD luteoviruses and PLRV were not detected (Table 1). Similar results were obtained by ISEM. In these tests, ScYLV was not detected by antisera against any of the five BYD luteoviruses, PLRV, BWYV, or BLRV.

Virion-associated proteins and nucleic acids. Purified virions of ScYLV contained a major $27-\mathrm{kDa}$ protein that was the only polypeptide detected by Coomassie blue staining (Fig. 3A). Additional proteins of 58 and 27 to $17 \mathrm{kDa}$ (six bands) were detected by western blotting with ScYLV antiserum (Fig. 3B, lane 2). Antibodies to BYDV-RPV also detected the 27- and 58-kDa bands and two of the six minor bands (Fig. 3B, lane 1). None of the proteins present in purified ScYLV virions were detected by antiserum to healthy sugarcane sap, and antiserum to ScYLV did not detect any similar bands in partially purified extracts of healthy sugarcane (data not shown).

Nucleic acid extracted from ScYLV virions migrated under denaturing conditions as a single species whose size was estimated at $5.8 \mathrm{~kb}$ (Fig. 2B). This component was completely digested by RNase and S1 nuclease but was unaffected by DNase (data not shown), confirming that ScYLV genomic nucleic acid is a singlestranded RNA.

\section{DISCUSSION}

Based on the results presented above, we concluded that ScYLV is a previously undescribed luteovirus that resembles other members of the group in particle properties, transmission by aphids but not by mechanical inoculation, and genome and capsid protein properties (25). The 58-kDa ScYLV protein detected by immunoblotting may be similar to the readthrough protein that has been reported to occur in virions of BYDV $(6,24,27)$ and PLRV (3). The series of minor bands that were also detected only by immunoblotting may represent degradation products of the native 27-kDa capsid protein. Such degradation may have been due to proteolysis by host plant proteases during the initial stages of virus purification when the virions were exposed for extended periods to enzymes present in crude extracts. Amplification of a portion of the ScYLV genome by reverse transcription polymerase chain reaction (RTPCR) amplification with luteovirus-specific oligonucleotide primers (8) supports the conclusion that ScYLV is a definitive member of the genus Luteovirus. Additional information on the nucleotide sequence and organization of the ScYLV genome will be needed to determine the relationship of ScYLV to other luteoviruses.

It was shown that ScYLV is related serologically to BYDV$\mathrm{RPV}$, and it was reported that luteovirus-like particles associated with YLS were related serologically to BYDV-PAV (23). There also has been a report of BYDV occurrence in sugarcane (11), although no YLS-like symptoms were described. However, ScYLV was not transmitted by either $M$. sacchari or R. maidis (14) from sugarcane to oats (Avena sativa cv. Clintland 64), which is highly susceptible to BYDV infection (17). These observations support the conclusion that ScYLV and BYDV are biologically distinct luteoviruses with a limited degree of antigenic relatedness.
There has been a consistent association between ScYLV and YLS $(14,22,23)$, and we present the following lines of evidence to support the hypothesis that ScYLV is the causal agent of one form of YLS of sugarcane. First, virions of ScYLV were detected consistently by EM and ISEM in partially purified extracts of YLSinfected sugarcane and were never detected in sugarcane that had no history of YLS. Second, no other virus-like particles were observed by EM in partially purified extracts of either YLS-infected or healthy sugarcane. Third, virions of YLS were detected consistently in partially purified extracts of sugarcane plants which developed typical YLS symptoms after inoculation by aphids that had fed on YLS-infected source plants. Neither YLS nor ScYLV was detected in plants infested with aphids from asymptomatic, YLS-free source plants; therefore, we have concluded that YLS symptoms in aphid-inoculated sugarcane were not elicited by aphid feeding per se or by any other virus-like agent that could be detected by EM in partially purified extracts. These data provide evidence, but not direct proof, that ScYLV is the causal agent of one form of YLS of sugarcane. More direct proof will need to be obtained using techniques such as transmission of ScYLV by aphid vectors that have acquired the virus from purified suspensions by membrane feeding or microinjection (17).

In our studies, ScYLV was transmitted only to sugarcane. However, recent studies in Hawaii (S. Schenck, personal communication) have shown that $S$. robustum, $S$. spontaneum, and $S$. sinensis are also natural hosts of ScYLV, and that ScYLV can be transmitted by $M$. sacchari from sugarcane to species of Erianthus, a close relative of Saccharum. If sugarcane were, in fact, the principal source of ScYLV inoculum, it would be feasible to propose a diseasemanagement strategy based on the use of virus-free planting material obtained by thermotherapy, followed by apical meristem culture. This approach has been effective in the case of PLRV (15), which, like ScYLV, is a luteovirus that occurs in a clonally propagated crop species. This strategy would permit the continued commercial use of sugarcane cultivars that have been selected for desirable agronomic and processing qualities as well as for resistance to other fungal, bacterial, and viral pathogens.

Although the results presented above indicate a consistent relationship between ScYLV infection and YLS in sugarcane, it should

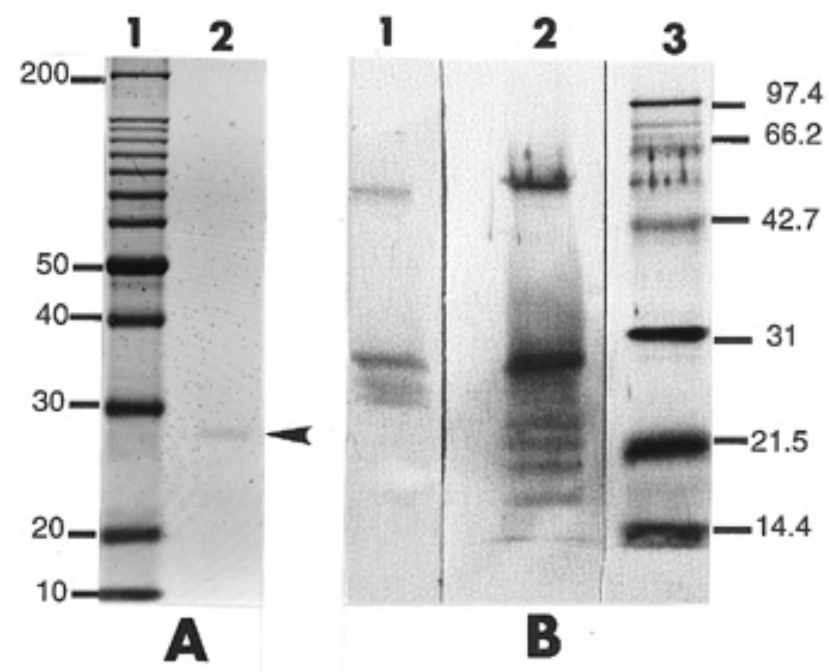

Fig. 3. Analysis of Sugarcane yellow leaf luteovirus (ScYLV) virion-associated polypeptides by sodium dodecyl sulfate polyacrylamide gel electrophoresis (SDS-PAGE) and immunoblotting. A, Detection of a single 27-kDa polypeptide (indicated by arrowhead) by Coomassie blue staining after SDS-PAGE (lane 2). Lane 1 contains molecular weight markers; sizes are indicated to the left. B, Multiple ScYLV virion-associated polypeptides detected by immunoblotting after SDS-PAGE. Lane 1, polypeptides detected by antibodies to a Barley yellow dwarf luteovirus RPV isolate; lane 2, polypeptides detected by antibodies to ScYLV; lane 3, biotinylated molecular weight markers; sizes are indicated to the right. 
be pointed out that, in Africa, midrib yellowing has been associated with phytoplasma infection in ScYLV-free sugarcane (9). We also reported above that ScYLV was not detected in some sugarcane samples from Costa Rica and Columbia that showed YLSlike symptoms. Midrib yellowing also can be induced in sugarcane by soft scale, Pulvinaria elongata, feeding (B. E. L. Lockhart, unpublished data). These observations suggest that midrib yellowing in sugarcane may be a generalized plant response to a variety of stress factors, including ScYLV infection. For this reason, we propose that the disease associated with ScYLV infection in sugarcane be referred to as viral yellow leaf syndrome to distinguish it from similar effects which may be elicited by other agents.

\section{ACKNOWLEDGMENTS}

Portion of a dissertation presented by S. M. Scagliusi to the University of Campinas, Brazil, in partial fulfillment of the requirements for the $\mathrm{Ph} . D$. degree. Published as 991220058 in MAES Journal Series. This research was supported by funds from the Brazilian National Research Council (CNPq-260025/95-0), the International Consortium for Sugarcane Biotechnology, and COPERSUCAR. We thank Novo-Nordisk Biochem North America, Inc., for providing generous supplies of Celluclast 1-5 L for use in this study; and J. C. Comstock, S. Schenck, M. Irey, E. Uliano, and J. Irvine for providing plant material used in this study.

\section{LITERATURE CITED}

1. Ahlawat, Y. S., Pant, R. P., Lockhart, B. E. L., Srivastava, M., Chakraborty, N. K., and Varma, A. 1996. Association of a badnavirus with citrus mosaic disease in India. Plant. Dis. 80:590-592.

2. Anonymous, 1994. Yellow leaf syndrome may be in Australia. Brisbane Sugar Exp. Stn. Bull. 48:14-15.

3. Bahner, I., Lamb, J., Mayo, M. A., and Hay, R. T. 1990. Expression of the genome of potato leafroll virus readthrough of the coat protein termination codon in vivo. J. Gen. Virol. 71:2251-2256.

4. Blackman, R. L., and Eastop, V. F. 1984. Aphids on the World's Crops. John Wiley \& Sons, Chichester, England.

5. Borth, W., Hu, J., and Schenck, S. 1994. Double-stranded RNA associated with sugarcane yellow leaf syndrome. Sugar Cane 3:5-8.

6. Cheng, S.-L., Domier, L. L., and D'Arcy, C. J. 1994. Detection of the readthrough protein of barley yellow dwarf virus. Virology 202:1003-1006.

7. Clark, M. F., and Adams, A. N. 1977. Characteristics of the microplate method of enzyme-linked immunosorbent assay for the detection of plant viruses. J. Gen. Virol. 34:475-483.

8. Comstock, J. C., Irey, M. S., Lockhart, B. E. L., and Wang, Z. K. 1998. Incidence of yellow leaf syndrome in CP cultivars based on polymerase chain reaction and serological techniques. Sugar Cane 4:21-28.

9. Cronjé, C. P. R., Tymon, A. M., Jones, P., and Bailey, R. A. 1998. Association of a phytoplasma with a yellow leaf syndrome of sugarcane in Africa. Ann. Appl. Biol. 133:177-186.

10. Laemmli, U. K. 1970. Cleavage of structural proteins during the assem- bly of the head of bacteriophage T4. Nature (Lond.) 227:680-685.

11. Lister, R. M., Aboul-Ata, A. E., El-Daoudi, Y. H., Marshall, D., Makkouk, K., Satour, M. M., Ghanem, E., and Burnett, P. A. 1994. Serotyping of barley yellow dwarf virus isolates from Egypt. Phytopathol. Mediterr. 33:152157.

12. Lockhart, B. E. L. 1990. Evidence for a double-stranded DNA genome in a second group of plant viruses. Phytopathology 80:127-130.

13. Lockhart, B. E. L., Autrey, L. J.-C., and Comstock, J. C. 1992. Partial purification and serology of sugarcane mild mosaic virus, a mealybugtransmitted closterolike virus. Phytopathology 82:691-695.

14. Lockhart, B. E. L., Irey, M. J., and Comstock, J. C. 1996. Sugarcane bacilliform virus, sugarcane mild mosaic virus and sugarcane yellow leaf syndrome. Pages 108-112 in: Sugarcane Germplasm Conservation and Exchange. B. J. Croft, C. M. Piggin, E. S. Wallis, and D. M. Hogarth, eds. Australian Centre for International Agricultural Research, Canberra.

15. Mellor, F. C., and Stace-Smith, R. 1977. Virus-free potatoes by tissue culture. Pages 616-635 in: Plant Cell, Tissue and Organ Culture. J. Reinert and Y. P. S. Bajaj, eds. Springer-Verlag, Berlin.

16. Ricaud, C. 1968. Yellow wilt of sugarcane in eastern Africa. Sugarcane Pathol. Newsl. 1:45-49.

17. Rochow, W. F. 1970. Barley yellow dwarf virus. Descrip. Plant Viruses No. 32. CMI/AAB, Kew, Surrey, England.

18. Schenck, S., and Hu, J. S. 1991. Update on the cause of sugarcane yellow leaf syndrome. Page 26 in: Proc. Hawaiian Sugar Technol. 1991. Hawaiian Sugar Planters Association, Honolulu.

19. Skopp, R. N., and Lane, L. C. 1988. Agarose gel electrophoresis of denatured RNA with silver staining. Anal. Biochem. 169:132-137.

20. Smith, G. R., Joyce, P. A., Handley, J. A., Sithijarn, P., Maugeri, M. M., Bernard, M. J., Berding, N., Dale, J. L., and Harding, R. M. 1996. Sugarcane: Research towards efficient and sustainable production. Pages 138140 in: Sugar 2000 Symposium. CSIRO, Division of Tropical Crops and Pastures, Brisbane, Australia.

21. Takanami, Y., and Kubo, S. 1979. Enzyme-assisted purification of two phloem-limited plant viruses: Tobacco necrotic dwarf and potato leafroll. J. Gen Virol. 44:153-159.

22. Vega, J. 1994. Sugarcane leaf yellowing syndrome: Evidence for association with virus. Summa Phytopathol. 20:50.

23. Vega, J., Scagluisi, S. M. M., and Ulian, E.-C. 1997. Sugarcane yellow leaf disease in Brazil: Evidence of association with a luteovirus. Plant. Dis. 81:21-26.

24. Wang, J. Y., Chay, C., Gildow, F. E., and Gray, S. M. 1995. Readthrough protein associated with virions of barley yellow dwarf luteovirus and its potential role in regulating the efficiency of aphid transmission. Virology 206:954-962.

25. Waterhouse, P. M., Gildow, F. E., and Johnstone, G. R. 1988. Luteovirus Group. Descrip. Plant Viruses No. 339. AAB, Wellesbourne, Warwick, England.

26. Waterhouse, P. M., and Helms, K. 1984. Purification of particles of subterranean clover red leaf virus using an industrial-grade cellulase. J. Virol. Methods 8:321-329.

27. Waterhouse, P. M., Martin, R. R., and Gerlach, W. L. 1989. BYDV-PAV virions contain readthrough protein. (Abstr.) Phytopathology 79:1215.

28. Wrigley, N. G. 1968. The lattice spacing of crystalline catalase as an internal standard of length in electron microscopy. J. Ultrastruct. Res. 24:454-464. 